\title{
The effects of nutrient run-off on fish productivity - considering the effects of stoichiometry
}

Author(s): $\quad$ F.H. Soudijn, K.E. van de Wolfshaar

Wageningen Marine Research

This research project was carried out by Wageningen Marine Research at the request of and with funding from the Ministry of Agriculture, Nature and Food Quality for the purposes of Policy Support Research Theme 'Biobased Circular Economy' (projectnummer KB-34-005-002).

CONFIDENTIAL no 
Keywords: Stoichiometry, nutrient run-off, zooplankton, fish productivity.

Client: $\quad$ Ministerie van Landbouw, Natuur en Voedselkwaliteit

Bezuidenhoutseweg 73

2594 AC, Den Haag

This report can be downloaded for free from https://doi.org/10.18174/539783

Wageningen Marine Research provides no printed copies of reports

Wageningen Marine Research is ISO 9001:2015 certified.

(C) Wageningen Marine Research

Wageningen Marine Research, an institute Wageningen Marine Research accepts no liability for consequential damage, nor within the legal entity Stichting for damage resulting from applications of the results of work or other data Wageningen Research (a foundation under obtained from Wageningen Marine Research. Client indemnifies Wageningen Dutch private law) represented by Marine Research from claims of third parties in connection with this application. Dr.ir. J.T. Dijkman, Managing director All rights reserved. No part of this publication may be reproduced and / or published, photocopied or used in any other way without the written permission of the publisher or author.

KvK nr. 09098104,

WMR BTW nr. NL 8113.83.696.B16.

Code BIC/SWIFT address: RABONL2U

IBAN code: NL 73 RABO 0373599285

A_4_3_2 V31 (2021) 


\section{Contents}

$\begin{array}{lr}\text { Visual summary } & 4\end{array}$

$\begin{array}{llr}1 & \text { Introduction } & 6\end{array}$

$2 \quad$ Processes involved, stoichiometry and fish productivity $\quad 7$

2.1 Background information: trophic transfer of nutrients $\quad 7$

2.2 Case study: Lake IJssel 8

3 Model case study: effects of stoichiometry on zooplankton development 11

3.1 Goals 11

3.2 Model description $\quad 11$

$\begin{array}{lll}3.2 .1 & \text { Life history model } & 11\end{array}$

3.2.2 Consumer-resource model 13

3.2.3 Nutrient regimes Lake IJssel 14

$\begin{array}{llr}3.3 & \text { Results } & 15\end{array}$

$\begin{array}{lll}\text { 3.3.1 Individual life histories } & 15\end{array}$

$\begin{array}{ll}\text { 3.3.2 Consumer resource dynamics } & 17\end{array}$

4 Discussion and conclusions $r$

5 Quality Assurance $r 2$

$\begin{array}{lr}\text { References } & 22\end{array}$

$\begin{array}{lr}\text { Justification } & 25\end{array}$ 


\section{Visual summary}
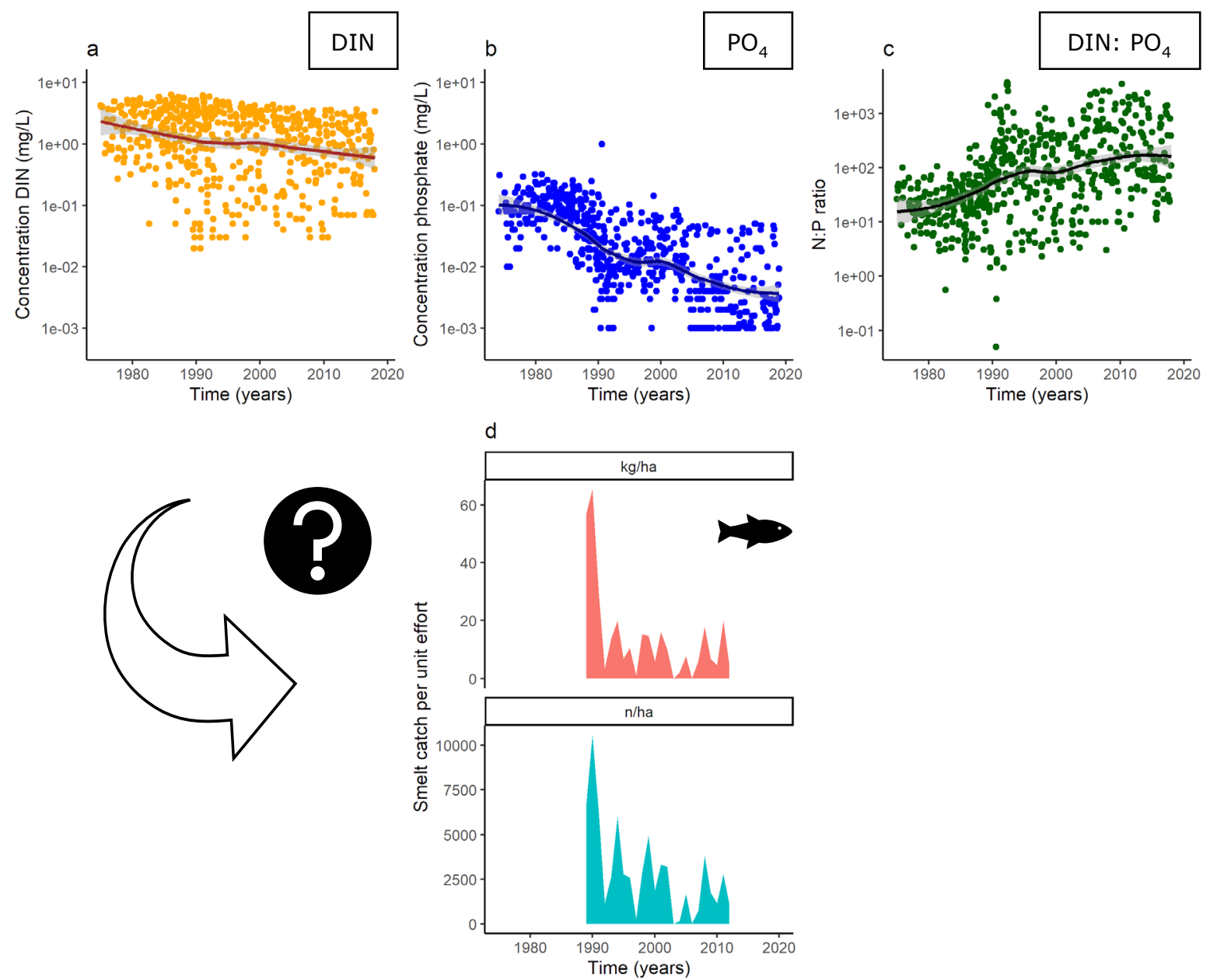

Figure 1 Changes through time of the (a) Dissolved Inorganic Nitrogen (DIN) and (b) phosphate $\left(\mathrm{PO}_{4}\right)$ concentrations (as a concentration per solved fraction) and (c) the ratio between the two in Lake IJssel. This report considers the potential link between the changes in nutrient concentrations and the change in fish biomass, such as (d) smelt catch per unit effort in biomass (top panel) and numbers (bottom panel) per hectare, in Lake IJssel. Sources: Nutrient concentrations at Vrouwenzand, sampling station in Lake IJssel (data RWS), Eurpean smelt catch per unit effort data (WMR). 


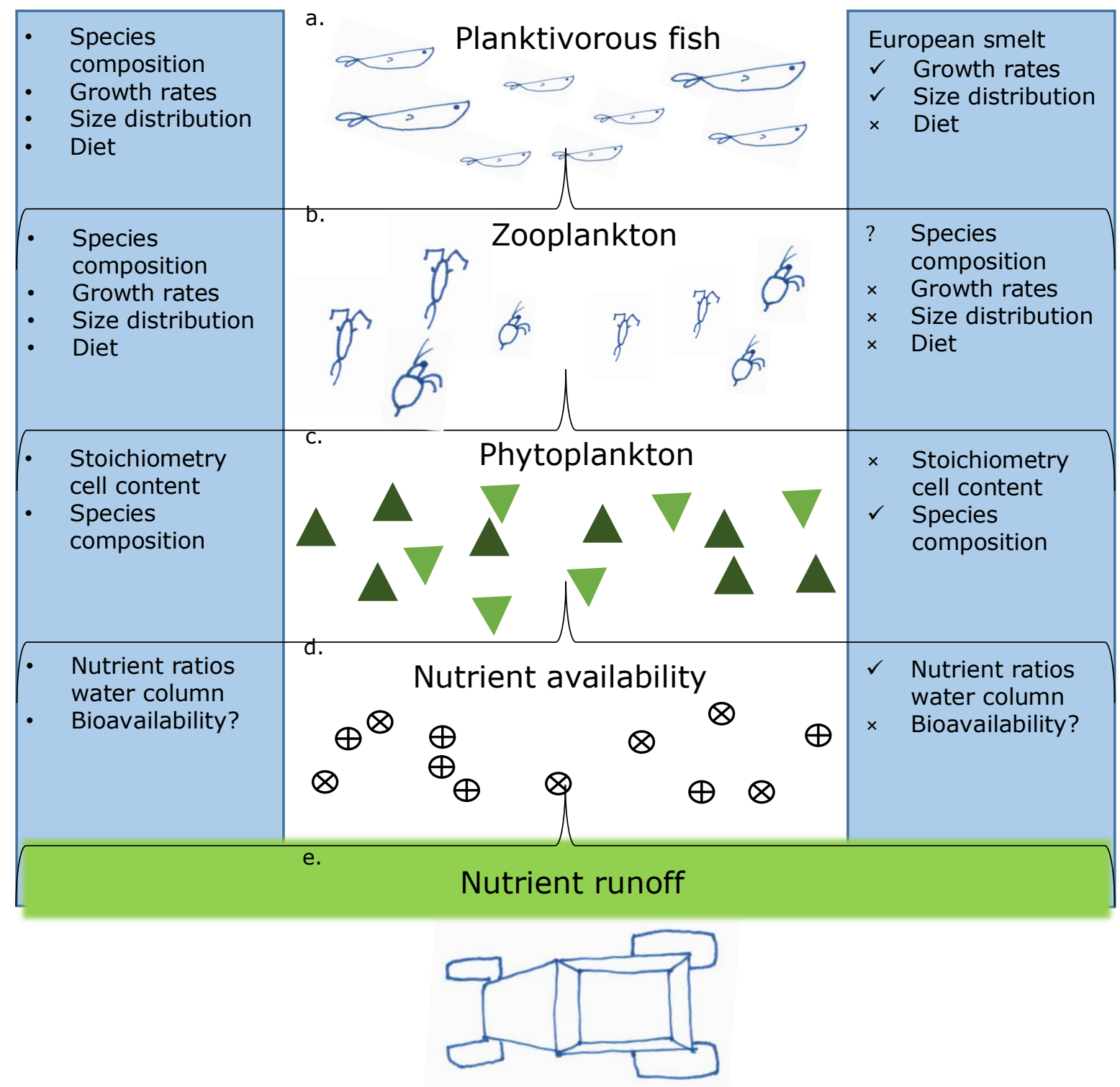

Figure 2 a) European smelt, different life stages; b) zooplankton: copepods and daphnids, different sizes/life stages; c: phytoplankton, different species; d: nutrients, different elements; e: tractor symbolizing agricultural and other sources of nutrient run off. List per panel with potential effects of changes in stoichiometry nutrient input (left) and information availability for Lake IJssel. 
Nutrient run-off from agricultural and urban lands is known to affect nutrient levels and algal production in fresh water ecosystems (Prater et al. 2017, Maranger et al. 2018). Extensive runoff may eventually lead to eutrophication and deterioration of the water quality and ecosystem. Protection of water quality and freshwater ecosystems is one of the main arguments for policy restrictions of runoff of fertilizers from agricultural land and nutrient loads in wastewater (e.g. van Gerven and Groenendijk 2020). Reduced water quality may affect drinking water provisioning and economic revenues from fishing or recreation. In addition, legislation to reach and maintain a good environmental status, both biochemically as well as ecologically, forces policy to take action (Water Framework Directive; 2000/60/EC). Moreover, current agreements on reduction of nutrient emissions to slow down or halt climate change will lead to further reduction of nutrient run-off to freshwater systems.

Fish productivity of fresh water systems relies on a combination of factors such as mixed layer depth, light intensity and nutrient availability (Karlsson et al. 2009). Fertilization of aquaculture fish ponds is a known way of increasing fish production (Diana et al. 1991). Nutrient runoff to streams due to wildfires and logging has been shown to affect primary productivity, benthic community composition and fish production (Silins et al. 2014). Fish production may be affected by phosphorus concentration through primary productivity (Downing et al. 1990). Yet, in addition to carbon, organisms require nutrients such as phosphorus and nitrogen. Food-chain productivity depends, in addition to total nutrient availability, also on stoichiometry, the nutrient composition (Sterner and Elser 2002). This implies that in addition to the total load of nutrients that enter a lake through run-off, the stoichiometry of the run-off may also affect freshwater ecosystems at different trophic levels. While phytoplankton species display a wide range of stoichiometry, zooplankton and fish species maintain homeostasis and the range of stoichiometry is much narrower per species (Waal et al. 2010).

Lake IJssel has experienced strong changes in $\mathrm{N}$ and $\mathrm{P}$ concentrations over the last 3-4 decades (decrease of 1 and 3 magnitudes of greatness for respectively $N$ and $P$, figure $1 a-b$ ). This is mostly due to the cleaner water inflow of German water through the river Rhine (Noordhuis 2010). In addition to changes of the total nutrient load, the N:P ratio has increased from about 1 to 10 (figure 1c.) On the one hand, it is thought that the changes in nutrient load have affected the phytoplankton species composition, which is visible in the size distribution of the phytoplankton (Noordhuis 2010). On the other hand, no shifts in functional species groups or chlorophyll productivity have been observed. The changes in nutrient loading and stoichiometry coincide with a sharp decline of the smelt (Osmerus eperlanus) biomass, the main pelagic planktivorous fish, in Lake IJssel (Figure 1d). Yet, it is unclear to what extend the changes in nutrient loads or stoichiometry are responsible for this because the changes in nutrients coincide with changes in other factors such as commercial fisheries effort, predation pressure by birds and water management.

Here we give an overview of known effects of stoichiometry on fish, zooplankton and phytoplankton. We consider Lake IJssel a case study for potential effects of (changes in) nutrient runoff on fish productivity. We identify potential effects, list the information that is available for all relevant trophic levels and processes and identify knowledge gaps. Finally, we hypothesize how the observed changes in stoichiometry may have affected the fish productivity and which knowledge is required to investigated these effects thoroughly. In the discussion we consider the broader perspective of the Lake IJssel food web and possible implications of changes in nutrient loading. 


\section{Processes involved, stoichiometry and fish productivity}

\subsection{Background information: trophic transfer of nutrients}

\section{Background information fish}

Fish maintain homeostasis, a balance of their internal environment, and the range of stoichiometry per species is therefore relatively narrow (Waal et al. 2010). Different species of fish have different nutrient requirements (Guo et al. 2018). In addition, fish in different life stages have different nutrient requirements and $\mathrm{N}$ and $\mathrm{P}$ content (Pilati and Vanni 2007). Phosphorus is important for bone formation and $\mathrm{P}$ content in fish diet is known to affect growth (Benstead et al. 2014). Experiments clearly show reduced growth in case of $P$ deficiency (Benstead et al. 2014). Yet, observations of $P$ limitation in fish growth are rare in nature (Schindler and Eby 1997). The reason for this is not clear. It has been observed that fish adapt their excretion of nutrients to the nutrient concentration of their food and nutrient requirements (Vanni et al. 2002, Pilati and Vanni 2007). Also, fish are capable of adjusting their food intake (rate and selectivity) to meet their required nutrient intake. It may thus be that $P$ limitation in nature is never so dire that it affects growth, or field observations may not be extensive enough to pick up on (potentially temporary) reduced growth due to P deficiency.

Based on this information, shifts in stoichiometry may result in changes in fish species composition (different nutrient requirements), diet (different/higher intake rate), somatic growth (changes in $\mathrm{P}$ content) and as a consequence of the last effect, changes in population size-distribution (Figure 2).

\section{Background information zooplankton}

Species of zooplankton such as copepods and cladocerans maintain homeostasis. Therefore, no large ranges of stoichiometry per species are observed in nature (Waal et al. 2010). Zooplankters are capable of adjusting their food intake (rate) and excretion to meet their required nutrient levels. Nutrient requirements differ per species of zooplankton, for example the cladoceran Bosmina (Hessen 1992, Schulz and Sterner 1999) and copepods (Andersen and Hessen 1991, Laspoumaderes et al. 2013) have lower $\mathrm{P}$ content and are more resilient to low $\mathrm{P}$ conditions than Daphnia. Zooplankton communities in lakes are often P limited (Hessen 1992), instead of C (energy) limited. In these cases, phytoplankton biomass and chlorophyll may not be indicative for zooplankton production, when the phytoplankton does not provide the needed nutrients (Sterner et al. 1998, Sarpe et al. 2014). Nutrient requirements differ per life stage and phosphorus availability affects growth in Daphnia (Prater et al. 2016). This is reflected by life-stage dependent intraspecific differences in nutrient content (VillarArgaiz et al. 2000, Ventura and Catalan 2005). As a consequence, stoichiometry of food may affect zooplankton population dynamics and size distributions (Richard and de Roos 2018).

Based on these findings, shifts in stoichiometry may result in changes in zooplankton species composition (different species have different nutrient requirements), diet, growth rates, and as a consequence of the last effect, changes in population size-distribution (Figure 2).

\section{Background information phytoplankton}

Phytoplankton species are flexible in stoichiometry, changes in stoichiometry nutrient input may directly result in changes in stoichiometry of phytoplankton (Waal et al. 2010). Phytoplankton stoichiometry is related to local nutrient concentrations (Prater et al. 2017). Still, minimum nutrient requirements are species specific (Rhee and Gotham 1980) and changes in stoichiometry of nutrient input may thus also result in shifts in species composition. In marine phytoplankton communities, nutrient ratios are relatively constant and close to the Redfield ratio, while in freshwater phytoplankton communities, nutrient ratios vary strongly across lakes and are generally not similar to the Redfield ratio at all (Hecky et al. 1993). Phytoplankton productivity in freshwater is mainly limited by $\mathrm{P}$ and in some seasons by N (Hecky and Kilham 1988, Hecky et al. 1993). In P-limited lakes, the 
algal molar C:P ratios may vary from 130:1 to 520:1 over the season (Hochstädter 2000), while zooplankton stoichiometry stays constant.

Based on these observations, changes in the stoichiometry of nutrient availability may result in changes in species composition and/or changes in stoichiometry of phytoplankton cells (Figure 2).

\section{Background information nutrient concentrations}

Changes in stoichiometry of nutrient inputs do not necessarily directly translate to changes in nutrient ratios in the water column. Hydrology, but also nutrient fluxes across the sediment-water interface shape the nutrient concentrations in the water column (Weigelhofer et al. 2018). In shallow water areas, the exchange of nutrients across the sediment-water interface is, in its turn, dependent on local water draw down and rewetting water management regimes (Vonk et al. 2017). Retention time of groundwater, seepage, land use and soil type are all factors that influence the relationship between nutrient values in soil and nutrient loads in surface waters (Yu et al. 2018). This implies that generalizations of terrestrial nutrient use and surface water stoichiometry cannot be made (Eertwegh 2002). To quantify the relation between terrestrial nutrient use and effects on biota is thus rather difficult. Ideally, regular measurements of phytoplankton and zooplankton stoichiometry are taken to provide insight in the nutrient fluxes in biological food chains.

\section{Ecosystem perspective}

Lake productivity depends on a balance between light and nutrient availability (Karlsson et al. 2009). In case lakes are nutrient limited, they are generally phosphorus limited. Besides run-off and atmospheric deposition, the excretion/death of biota is an important source of $\mathrm{N}$ and $\mathrm{P}$ for phytoplankton in lakes. Fish contribute less to nutrient cycling within lakes than plankton (Griffiths 2006). In addition, predation affects the phytoplankton composition and hereby, the zooplankton community structure may affect the nutrient content of the phytoplankton (Elser et al. 1988). Different species of zooplankton have different nutrient requirements and the zooplankton species composition affects the nutrient recycling in the ecosystem. Zooplankton in its turn, is affected by the interplay between algal stoichiometry and fish predation (Hall et al. 2004). Fish abundance may thus eventually, through changing the zooplankton species composition top-down, affect the stoichiometry of the phytoplankton.

Since nutrient requirements of zooplankton and fish are life stage dependent, changes in stoichiometry may lead to growth retardation (Richard and de Roos 2018). Growth retardation may lead to population bottlenecks and shifts in population size distributions. Planktivorous fish species have a size specific diet preference (Brooks 1968). Through size-dependent predation, changes in size distributions may cascade through food chains (Van Leeuwen et al. 2008, Soudijn and de Roos 2017). Changes in size-distribution of the zooplankton may thus in turn have an effect on the consumers of zooplankton, such as fish. The actual (stoichiometric) food web dynamics under different nutrient ratios are thus likely to be rather complex, with a lot of potential indirect effects. Here, we aim to consider potential effects of stoichiometric changes in the phytoplankton on growth and populationdynamics of higher trophic levels such as fish and zooplankton. We focus on bottom-up effects of changes in algal stoichiometry on the higher trophic levels.

\subsection{Case study: Lake IJssel}

\section{Lake IJssel Fish}

The biomass and abundance of European smelt in Lake IJssel show a decrease since the 1970s. Figure 1 shows smelt data from 1989 onwards, the sampling programme was standardized at this point (van Rijssel et al. 2019). While the changes in nutrient concentrations in Lake IJssel coincide with the decrease of smelt there could be numerous other factors that caused the change. Examples of such causes are the commercial exploitation of smelt, changes in hydrological regime and changes in the Lake IJssel food web (de Leeuw et al. 2019).

The main planktivore in Lake IJssel is European smelt. In addition, the piscivores in the lake are also planktivorous during their juvenile stages. European smelt is predominantly planktivorous up to $15 \mathrm{~cm}$ and from $15 \mathrm{~cm}$ upwards shifts to a piscivorous/macrofauna diet (de Leeuw et al. 2006). The main part of the smelt population in Lake IJssel is smaller than $10 \mathrm{~cm}$. 
During its planktivorous phase, smelt diet is composed of several types of zooplankton (table 2-1). The zooplankton nutrient content and body size differs per species (table 2-1). Diet requirements for smelt, such as nutrient requirements $(\mathrm{N}: \mathrm{P})$ and prey size preference, are unknown. No consistent recordings of smelt diet through time are available for Lake IJssel.

Growth data of smelt are available for some years: 1987-88 (Van Zuilekom 1991), 1995-96, 2000, and 2010-11 (WMR data base). A comparison of these growth patterns could give an indication of changes between 1987/88 and the current days, however, no growth data are available from the earlier period when smelt displayed even higher abundance in Lake IJssel. In addition, the phosphorus requirements of smelt are probably highest in the larval stage, since growth in the larval and juvenile stages of fish is phosphorus intensive (e.g. Pilati and Vanni 2007), for which growth was never monitored.

\section{Table 1}

Common zooplankton groups and species in the diet of European smelt in Lake IJssel (zooplankton species group, nutritional value per gram wet weight, body size range and typical $N$ and $P$ composition

\begin{tabular}{|c|c|c|c|}
\hline Zooplankton & Caloric content ${ }^{6}$ & Body size range & N:P ratio \\
\hline Daphnia & $314 \mathrm{Cal} / \mathrm{g}$ & $1-5 \mathrm{~mm}^{1}$ & $6.7^{5}$ \\
\hline Bosmina & $321 \mathrm{Cal} / \mathrm{g}$ & $0.25-0.3 \mathrm{~mm}^{2}$ & $11.9^{5}$ \\
\hline Chydorus & $202 \mathrm{Cal} / \mathrm{g}$ & $0.17-0.49 \mathrm{~mm}^{3}$ & - \\
\hline Cyclops vernalis & $108 \mathrm{Cal} / \mathrm{g}$ & $0.5-5 \mathrm{~mm}$ & 19.2 (copepods) $^{5}$ \\
\hline
\end{tabular}

Lake IJssel zooplankton

The zooplankton in lake IJssel is composed of the species groups: rotifers, cladocerans (daphnids, Bosmina, Chydorus) and some copepod (e.g. Cyclops vernalis) species. There is no consistent monitoring of the zooplankton community in lake IJssel. For different projects and purposes, the zooplankton community has been sampled on several occasions by different organizations. In 1987 and 1988 by Tom Buijse (RIZA), 1992-95 by RIZA, 1992 and 1997-2001 for the MWTL and in 1996 by Aquasense. However, the data are not optimal for a comparison of zooplankton community composition before and after the changes in stoichiometry occurred. The samplings were executed in different periods of the year with different choices regarding the resolution and grouping of species identification and use different units in their reporting of results.

The diet requirements of zooplankton are not known for Lake IJssel in detail. Generally, small zooplankton (such as rotifers and small cladocerans; Table 1) consumes phytoplankton up to a size of $30 \mu \mathrm{m}$ (Noordhuis 2010). Larger cladocerans (e.g. certain daphnids) could consume algae up to $50 \mu \mathrm{m}$ and larger particles can only be eaten by adult copepods and amphipods. The differences in N:P ratio of the zooplankton groups eaten by European smelt (Table 1) give an indication of differences in nutrient composition and requirements of the zooplankters. For example, daphnia have a higher $\mathrm{P}$ content and $\mathrm{P}$ requirement than copepods (Table 1). Since Daphnia is relatively large in size and moves slower than for example copepods, it is preferred as food by smelt.

The available (sparse) sampling of zooplankton in Lake IJssel could perhaps give an indication of shifts in species composition due to changes in stoichiometry. There are no data available regarding the diet (stoichiometry) of zooplankton in different periods and neither is there information available regarding the growth patterns of zooplankton and/or the population size distributions.

\section{Lake IJssel Phytoplankton}

The chlorophyll concentrations in lake IJssel seem to be unaffected by the changes in stoichiometry in the nutrient availability and total nutrient levels (Noordhuis 2010 fig. 5.1.3). Data regarding the phytoplankton species composition is available from 1992-Now (Noordhuis 2010). Unfortunately there is no overlap between the phytoplankton sampling and the early years with high phosphorus loads ( 70 s and $80 \mathrm{~s}$, figure 1 ). Since the $90 \mathrm{~s}$, the composition of functional species groups of phytoplankton 
has remained the same (Noordhuis 2010 fig. 5.1.15). Yet, the size distribution of the phytoplankton has changed, with a relatively higher biomass of smaller phytoplankton species in more recent years (Noordhuis 2010 fig. 5.1.8 and 5.1.13). Potentially, the change in size-distribution of the phytoplankton is an indication of a change in predation pressure by the zooplankton (Noordhuis 2010). Such a change could have resulted from a shift in the zooplankton composition due to changes in stoichiometry of the phytoplankton or due to changes in fish predation pressure. However, there is no information available regarding the stoichiometry of the phytoplankton. It seems likely that the changes in nutrient availability in the water column are reflected in changes in stoichiometry in the phytoplankton due to their flexibility in their uptake of nutrients. In addition, it is thought that the reduction of phosphorus in Dutch inland freshwaters has led to reduced phosphor availability and even phosphor limitation of phytoplankton communities along the North Sea coast (Burson et al. 2016).

There are data available of the phytoplankton species composition (from the 90s-now), but no information regarding the stoichiometry of the phytoplankton.

\section{Lake IJssel Nutrients}

In Lake IJssel, the changes in nutrient concentrations are mostly due to the reduction of nutrients in the German river Rhine water. Improvement of wastewater treatment in Germany underlie the reductions of phosphor (since 1970s) and nitrogen (since 1980s) (Noordhuis 2010). Local terrestrial run-off will undoubtedly affect the nutrient concentrations in local freshwater bodies. The relationship between terrestrial run-off and the nutrient concentration in Lake IJssel is so far unresolved. 


\section{Model case study: effects of stoichiometry on zooplankton development}

\section{$3.1 \quad$ Goals}

While phytoplankton has quite some flexibility in their nutrient requirements and nutrient composition of their cells, animals maintain homeostasis and require certain amounts of nutrients for growth. Changes in nutrient limitation can therefore affect animal growth patterns. Most multitrophic models consider only the effect of changes in energy (carbon) on population dynamics and the trophic transfer efficiency. The consideration of the effect of changes in nutrient requirements calls for a different approach than usual. As a first step we investigate the effect of phosphorus limitation on zooplankton development. In 2020, we aim to complete steps 1 and 2.

Consequently, we aim to proceed to determine effects of nutrient limitation on aquatic systems in (a number of) the following steps:

1. Effect of nutrient limitation on individual development of zooplankton - with the Daphnia model described below, we determine growth patterns for different environmental conditions in Lake IJssel.

2. Effect of nutrient limitation on population dynamics of zooplankton - make and extension of the Daphnia model described below to allow for this analysis, consider changes in daphnid size distributions.

3. Consequences of potential shifts in zooplankton for smelt food availability.

4. Effect of nutrient limitation of individual development and population dynamics of different species of zooplankton - parameterize model below for two different species of zooplankton that are important in lake IJssel and repeat steps 1 and 2 .

5. Effect of shifts in nutrient limitation on competition between zooplankton species - use models developed in step 3 in competition setting and compare with patterns observed in Lake Ijssel.

6. Effect of nutrient limitation on grazing of zooplankton on phytoplankton - develop size spectrum of phytoplankton species (nutrient dependent growth) and show (seasonal) development patterns of phytoplankton for different nutrient conditions. Compare to data of lake IJssel phytoplankton size spectrum.

7. Effect of shift of nutrient limitation from $\mathrm{P}$ to $\mathrm{N}$ limitation - need to reparametrize the model such that $\mathrm{N}$ limitation can be considered.

8. Effect of nutrient limitation on phytoplankton - zooplankton - fish system - need to extend model developed in step 2 and/or 4 with a fish population.

9. Effect of nutrient limitation in different ontogenetic stages - find data for shifts in nutrients requirements with ontogeny (fish and zooplankton), incorporate in steps 1-7 above.

\subsection{Model description}

\subsubsection{Life history model}

Following Richard and de Roos (2018), we use a size-structured model with two nutrient components ( $\mathrm{C}$ and $\mathrm{P}$ ) to project the nutrient content and development of Daphnia. The nutrient composition in soma and neonate tissues is assumed constant.

The food ingestion is defined as:

$$
I(W, F)=\frac{F}{F+F_{h}} v W,
$$

with the food density $F$, half saturation density $F_{h}$, maximum ingestion rate $v$ and body weight $W$.

The biomass of carbon and phosphorus available for production follows: 


$$
\begin{aligned}
& \omega_{C}(W, F)=\sigma_{C} I(W, F)-m_{C} W, \\
& \omega_{P}(W, F)=\sigma_{P} \frac{I(W, F)}{\phi_{F}}-\frac{m_{P}}{\phi_{B}} W .
\end{aligned}
$$

The production terms depend on the ingested carbon biomass $I$, the conversion efficiencies $\sigma_{C}$ and $\sigma_{P}$ for respectively carbon and phosphorus, the mass-specific metabolic maintenance rates $m_{C}$ and $m_{P}$ for respectively carbon and phosporus, and, the C:P ratio of the ingested food $\phi_{F}$ and the soma $\phi_{B}$. While juveniles, individuals with a body weight $W$ smaller than $W_{j}$, invest all available energy in growth, adults, individuals larger than $W_{j}$, invest in both growth and reproduction. The proportion of energy invested in growth is defined as:

$$
\theta(W)=\left\{\begin{aligned}
1, & W<W_{j} \\
\frac{1}{1+r(W-W j)}, & W \geq W_{j}
\end{aligned}\right.
$$

The allocation is dependent on allocation parameter $r$.

The energy sequestered in growth for carbon $G_{C}$ and phosphorus $G_{P}$, are defined as:

$$
\begin{aligned}
& G_{C}=\gamma_{C G} \theta(W) P_{C}(W, F), \\
& G_{P}=\frac{\gamma_{C G}}{\phi_{B}} \theta(W) P_{C}(W, F) .
\end{aligned}
$$

These terms depend on the fraction of carbon $\gamma_{C G}$ that ends up in the tissues and the C:P ratio of the soma $\phi_{B}$.

and the energy invested in reproduction for carbon $R_{C}$ and phosporus $R_{P}$ are defined as:

$$
\begin{aligned}
& R_{C}=\gamma_{C R}(1-\theta(W)) P_{C}(W, F), \\
& R_{P}=\frac{\gamma_{C R}}{\phi_{B}}(1-\theta(W)) P_{C}(W, F) .
\end{aligned}
$$

All four of these equations depend on the carbon invested in biomass production $P_{C}(W, F)$ and depend on the assumption of constant nutrient composition $\phi_{B}$ of the soma and neonates. The parameters $\gamma_{C G}$ and $\gamma_{C R}$ represent the fractions of carbon based energy allocated to respectively growth and reproduction that end up in the tissues.

The nutrients invested in biomass production can be described by:

$$
\begin{aligned}
& P_{C}(W, F)=\min \left(\omega_{C}(W, F), \phi_{z}(W) \omega_{P}(W, F)\right), \\
& P_{P}(W, F)=\frac{\min \left(\omega_{C}(W, F), \phi_{z}(W) \omega_{P}(W, F)\right)}{\phi_{z}(W)} .
\end{aligned}
$$

The biomass production is in both cases dependent on the minimum availability of nutrients after maintenance. The flux $\phi_{z}(W)$ represents the nutrient composition of the biomass production and is defined as:

$$
\phi_{z}(W)=\frac{\phi_{B}}{\theta(W) \frac{\gamma_{C G}}{\gamma_{P G}}+(1-\theta(W)) \frac{\gamma_{C R}}{\gamma_{P R}}}
$$

with the parameters $\gamma_{P G}$ and $\gamma_{P R}$ that represent the fractions of phosphorus based energy allocated to respectively growth and reproduction that end up in the tissues.

The above results in the following ordinary differential equation for the change of somatic weight $W$ for an individual with age $a$ :

$$
\frac{d W}{d a}=\gamma_{C G} \theta(W) P_{C}(W, F),
$$

and the function to describe the energy invested in reproduction $B$ as function of weight is:

$$
B(W)=\gamma_{C R}(1-\theta(W)) P_{C}(W, F) \text {. }
$$

The model is parameterized with the values previously described for the physiological requirements of carbon and phosphorus of Daphnia by Richard and de Roos (2018). The values are given in Table 2. We consider the effect of changes in parameter $\phi_{F}$, the C:P ratio of the food source on the individual level development.

Table 2 Default values of parameters in the model, following Richard and de Roos (2018)

\begin{tabular}{clll} 
Parameter & Description & Value & unit \\
\hline$F$ & Food concentration & 1 & $\mathrm{mg} \mathrm{C} / \mathrm{L}$ \\
$F_{h}$ & Half saturation constant & 0.164 & $\mathrm{mg} \mathrm{C} / \mathrm{L}$
\end{tabular}




\begin{tabular}{|c|c|c|c|}
\hline$v$ & Mass-specific maximum ingestion rate & 2.5 & $d^{-1}$ \\
\hline$\phi_{F}$ & $C: P$ ratio food source & varied & - \\
\hline$\sigma_{C}$ & conversion efficiency carbon & 0.53 & - \\
\hline$\sigma_{P}$ & conversion efficiency phosphor & 0.97 & - \\
\hline$m_{C}$ & $\begin{array}{l}\text { Mass-specific metabolic maintenance rate } \\
\text { carbon }\end{array}$ & 0.08 & $d^{-1}$ \\
\hline$m_{P}$ & $\begin{array}{l}\text { Mass-specific metabolic maintenance rate } \\
\text { phosphor }\end{array}$ & 0.03 & $d^{-1}$ \\
\hline$W_{j}$ & Size at maturation & 0.49 & $\mu \mathrm{mol} \mathrm{C}$ \\
\hline$r$ & allocation parameter & 5.1 & $\mu \mathrm{mol} \mathrm{C} C^{-1}$ \\
\hline$\gamma_{C G}$ & fraction of carbon that ends up in soma & 0.31 & - \\
\hline$\gamma_{P G}$ & fraction of phosphor that ends up in soma & 1 & - \\
\hline$\phi_{B}$ & $C: P$ ratio of the soma & 100 & - \\
\hline$\gamma_{C R}$ & $\begin{array}{l}\text { fraction of carbon that ends up in reproductive } \\
\text { tissues }\end{array}$ & 0.63 & - \\
\hline$\gamma_{P R}$ & $\begin{array}{l}\text { fraction of phosphor that ends up in } \\
\text { reproductive tissues }\end{array}$ & 1 & - \\
\hline$W_{b}$ & Mass at birth & 0.09 & $\mu \mathrm{mol} \mathrm{C}$ \\
\hline$R_{\max }$ & Maximum resource density & 1.0 & $\mathrm{mg} \mathrm{C/L}$ \\
\hline$\rho$ & Resource turn-over rate & 1 & \\
\hline$\mu$ & background mortality rate & 0.0015 & $d^{-1}$ \\
\hline
\end{tabular}

\subsubsection{Consumer-resource model}

The life history model described in the previous section can be extended to a dynamics consumerresource model. Here, the consumption rate of the consumer affects the density and growth rate of the resource. The density of the resource affects, on its turn, the growth rate of the consumer.

We implement a consumer-resource model with semi-chemostat growth in the resource similar to the size-structured consumer-resource model previously described by de Roos and Persson (2013). The nutrient ratio in the resource is assumed constant through time, we study the effect of varying this parameter on the asymptotic behaviour of the consumer-resource model.

The dynamics of resource $R$ over time $t$ follow, in absence of the consumer, semi-chemostat growth. The resource is, when the consumer is present, reduced by grazing of the consumer:

$$
\frac{d R}{d t}=\rho\left(R_{\max }-R\right)-E(c(t, W)),
$$

with resource turn-over rate $\rho$, maximum resource density $R_{\max }$, grazing rate $E$ and consumer sizedistribution $c(t, W)$.

The change in the consumer size-distribution $c(t, W)$ through growth $g(R, W)$ and mortality $d(R)$ can be described by:

$$
\frac{\partial c(t, W)}{\partial t}+\frac{\partial g(R, W) c(t, W)}{\partial W}=-d(R, W) c(t, W)
$$

New-born individuals continuously enter the population, following:

$$
g\left(R, W_{b}\right) c\left(t, W_{b}\right)=b(R, c(t, W)),
$$

where $b(R, c(t, W))$ represents the total birth-rate.

The growth rate of an individual can be deduced from the equations defined at the individual-level and is equal to:

$$
\partial g(R, W)=\gamma_{C G} \theta(W) P_{C}(W, R),
$$

where the food level $F$ is now equal to the resource density $R$. After reaching the size at maturation $W_{j}$, individuals invest in reproduction as well as growth (3.2.1). The mortality rate is size dependent as individuals suffer from, in addition to background mortality $\mu$, starvation mortality when the resource ingestion does not cover the maintenance costs for carbon or phosphorus, the mortality rate is thus defined as: 


$$
d(R, W)=\mu-\min \left(0, P_{C}(W, R)\right),
$$

where the feeding level is equal to the resource density and the negative carbon energy production is subtracted to the mortality rate.

The total population birth rate is defined as:

$$
b(R, c(t, W))=\int_{W_{b}}^{\infty} c(t, W) B(W) d W,
$$

where the feeding level is again equal to the resource density and the reproduction rate per individual is multiplied with the population density function $c(t, W)$, integrated over the full population size range. The grazing rate of the resource by the consumer $E$ is defined as:

$$
E(c(t, W))=\int_{W_{b}}^{\infty} c(t, W) I(W, R) d W,
$$

where the feeding level is again equal to the resource density and the food ingestion per individual is multiplied with the population density function $c(t, W)$, integrated over the full population size range.

The allometric relationship:

$$
L(W)=\left(\frac{W}{0.22}\right)^{\frac{5}{12}},
$$

was used to convert weight (in $\mu \mathrm{mol} \mathrm{C}$ ) to lenght (in $\mathrm{mm}$ ).

The model is parameterized the same as the life history model. For the background mortality, resource turn-over rate and maximum resource density we chose values that allow for coexistence of the resource and the consumer. The values are given in Table $\mathbf{2}$. We consider the effect of changes in parameter $\phi_{F}$, the C:P ratio of the food source on the individual level development.

\subsubsection{Nutrient regimes Lake IJssel}

There is large variation in the conversion factor of particulate organic carbon (POC) to phytoplankton chlorophyll a, from about 100-500, which depends on temperature, nutrient availability (P and N) and growth rate of the phytoplankton (Riemann et al. 1989). In addition, the percentage of carbon content of the cell made up of chlorophyll a varies also, but only between about 2-5\% (Riemann et al. 1989). There is no straightforward conversion factor from POC to carbon content of the phytoplankton community. Also, the translation of $\mathrm{P}$ or $\mathrm{PO}$ concentration to mean $\mathrm{P}$ content of the cells on the community level is not known.

RWS tracks concentrations of several measures of the nutrients in the surface water of lake IJssel. We consider the concentrations of hydrogen carbonate and calcium carbonate as indicative for the $\mathrm{C}$ availability, but while hydrogen carbonate was measured between 1975 - 1981, calcium carbonate was measured between 2006-2017. There is thus no consistent measure of C availability for phytoplankton at lake IJssel. Dissolved total phosphorus is taken as indicative for the P availability for phytoplankton. For nitrogen we consider dissolved Kjeldahl, or total dissolved nitrogen. The measurements are all taken at the measuring location "Vrouwenzand".

The N:P ratio in Lake IJssel increased steadily through time. The concentrations of both $\mathrm{N}$ and $\mathrm{P}$ decrease over time (Figure 1), but the $\mathrm{P}$ concentration decreases much more rapidly. Based on the mean N:P ratios before 1990 ( 40) and after 2005 ( 500), we may conclude that the environmental factors have moved towards a situation of severe $\mathrm{P}$ limitation.

We do not have a measure for the variation in the P content of food available to zooplankton in Lake IJssel. Phytoplankton stoichiometry is related to local nutrient concentrations, but there is no clear quantitative relationship known (Prater et al. 2017). Generally, C and N seem to be interrelated and in addition, vary less than P (Sterner and Elser 2002, Sterner et al. 2008, Prater et al. 2017). For N:P> 22 and C:P > 258 in phytoplankton cells, phytoplankton growth is severely P limited (Hecky et al. 1993). A C: $P$ ratio between $129-258$ is considered a moderately $P$ limited situation. In addition to nutrient availability, phytoplankton stoichiometry depends on light (Dickman et al. 2006). The nutrient 
concentrations in the water column indicate that there could have been a shift to a situation with severe phosphorus limitation. The initial situation is unclear, but we will assume that Lake IJssel was initially moderately phosphorus limited. To mimic a situation with moderate phosphorus limitation, we assume a C:P ratio in the phytoplankton, the resource in the model, of 200 . For the severely phosphorus limited situation, we assume that the observed shift in nutrient concentrations in the water column has resulted in a maximal C:P ratio in the phytoplankton, the food source in the model, of 1000 . Higher $C: P$ ratios in cell content are assumed unviable for algae. We investigate the effect of such a shift in C:P ratio in the food source, parameter $\phi_{F}$ in the model, on the life history development of daphnia (Figure 4).

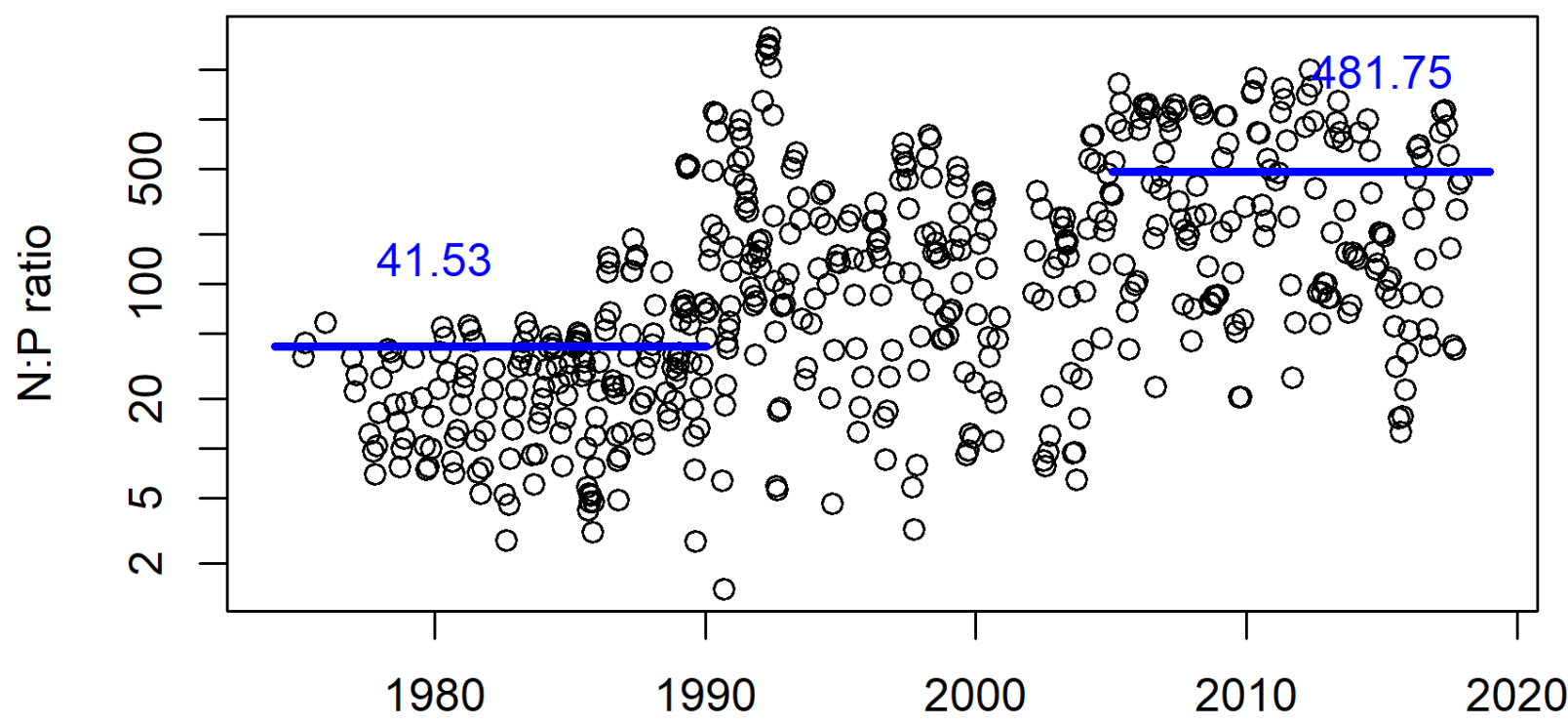

\section{Date}

Figure 3 Dissolved nitrate + nitrite + ammonium and dissolved total phosphorus in lake IJssel, N/P ratio. We consider two periods with relatively much (1970s-1980s) and little (2010s) phosphorus. Moving average ( 3 months) of N:P ratios in lake IJssel.

\subsection{Results}

\subsubsection{Individual life histories}

The emergence of severe phosphorus limitation in daphnia such as shown in Figure 4, results in a strongly reduced growth rate and significantly smaller amount of offspring being produced. The broad range of $\mathrm{N}$ : P ratios observed in lake IJssel (Figure 3 ) indicates that a shift from moderate to severe phosphorus limitation may very well have occurred in Lake IJssel. A comparison of the mean N:P ratio in the 1980s vs the 2010s (Figure 3), shows that there could have been a shift to severely phosphor limited growth of zooplankton in Lake IJssel (Figure 5). Especially so, if the concentration of the solved fractions of $\mathrm{N}$ and $\mathrm{P}$ are indicative for phytoplankton stoichiometry in the lake. While the shifts in the C:P ratio that we used in the model perhaps seem somewhat extreme, an experimental study showed shifts in phytoplankton C:P from 200 to 400 after 48 hours due to manipulations of light intensity in flasks (Dickman et al. 2006). This indicates that strong shifts in C:P ratios in phytoplankton are possible, even over a short time span.

A change in nutrient ratios towards a situation with $\mathrm{P}$ limitation can have strong effects on organisms at higher trophic levels. The changes such as shown in these figures (Figures 4 and 5) could potentially lead to changes in zooplankton size distributions and/or species composition. This would also mean that the food availability and/or quality for fish potentially could be affected. 

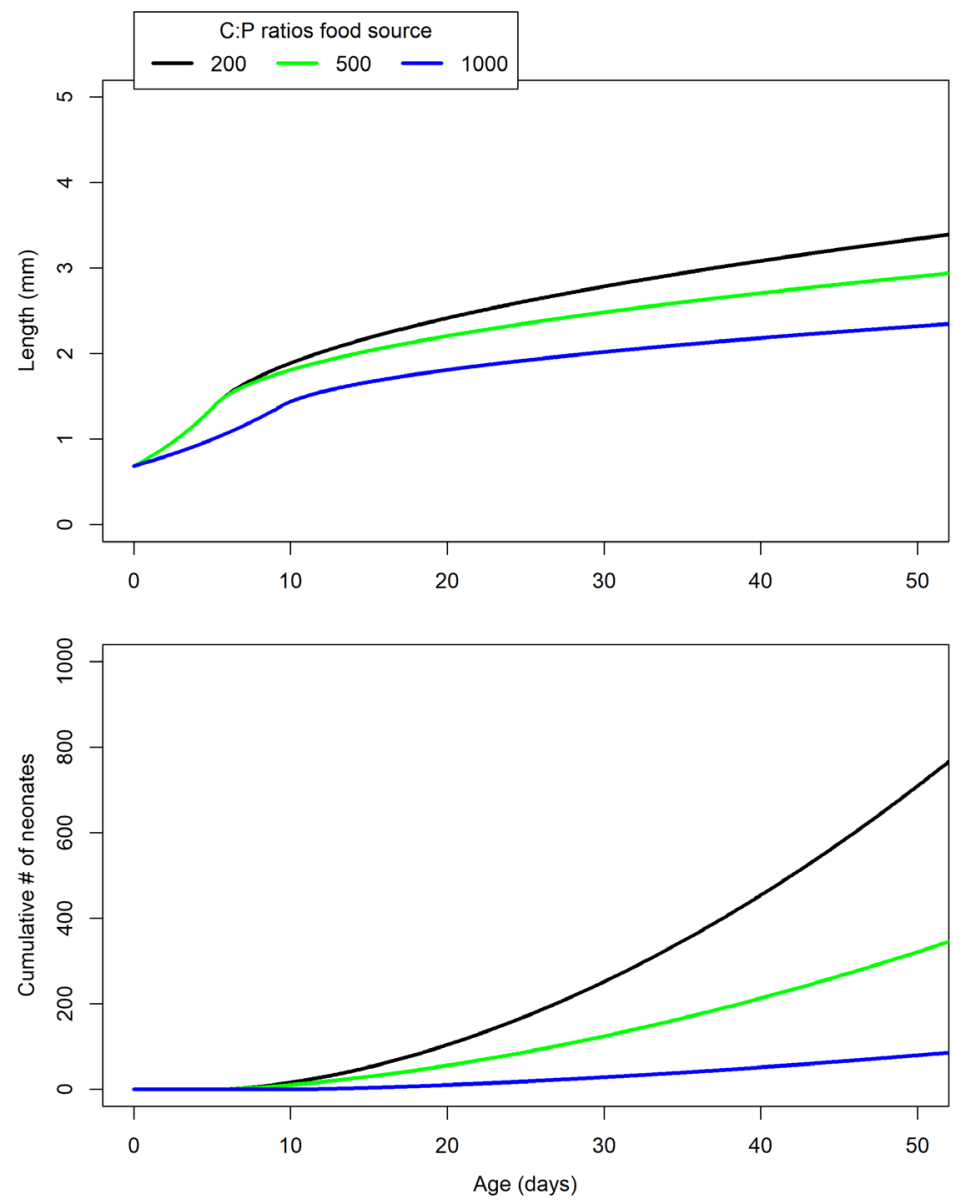

Figure 4 Effect of shift from carbon to phosphor limitation on individual-level development of Daphnia. The C:P ratio in the food source $\phi_{F}$ varies from 200,500, to a 1000. 

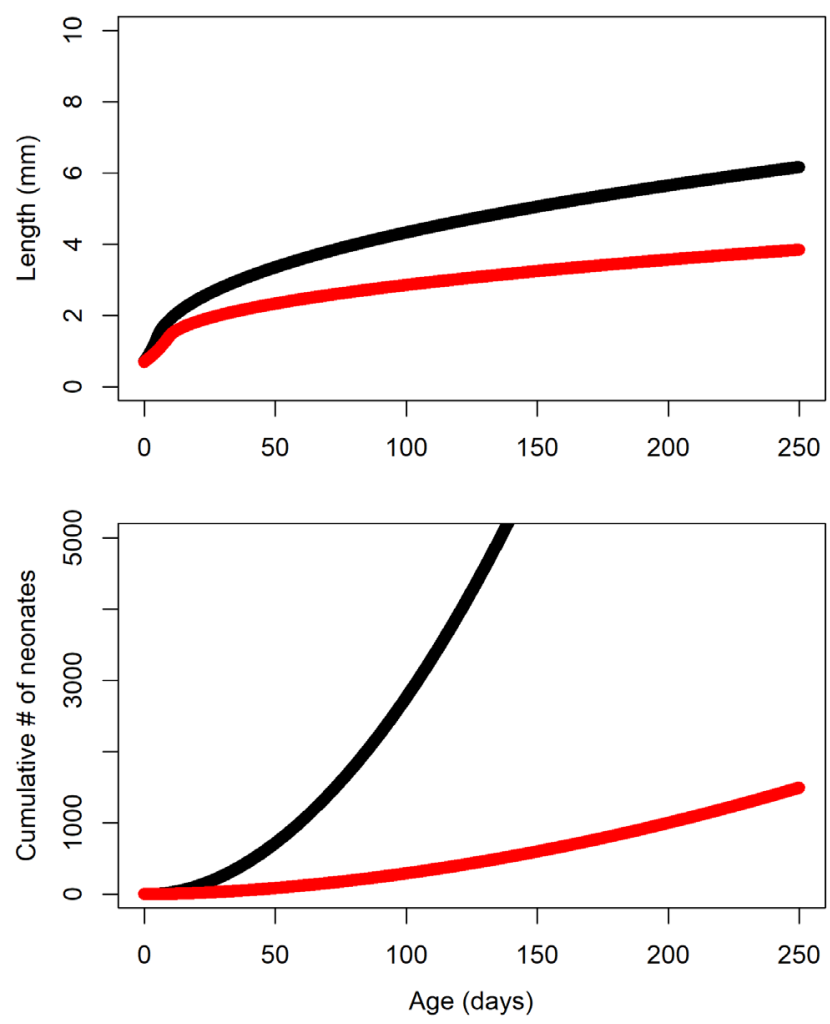

- $80 \mathrm{~s} \cdot 10 \mathrm{~s}$

Figure 5 Growth and number of offspring produced by Daphnia for several values of C:P ratio in the food source $\phi_{F}$. We used a C:P ratio in the food source with moderate ( $\left.\phi_{F}=200,1970-80 \mathrm{~s}\right)$ and severe $\left(\phi_{F}=1000,2000-10\right.$ s) $P$ limitation, based on the changes in concentrations of $C$ and $P$ in Lake IJssel.

\subsubsection{Consumer resource dynamics}

The consumer abundance in the consumer-resource model is either limited by the carbon or the phosphorus availability. This depends on the C:P ratio of the (phytoplankton) resource (Figure 6). For the change of a moderately $\mathrm{P}$ limited to a severely $\mathrm{P}$ limited system, we consider the consumerresource dynamics for respectively a value of $\phi_{F}=200$ and $\phi_{F}=1000$. The overall consumer biomass is lower for severe P limitation because the limited amount of phosphorus present in the system starts limiting the carrying capacity of consumers. In addition, the population size distribution changes for severe $\mathrm{P}$ limitation compared to moderate $\mathrm{P}$ limitation. The decrease in juvenile biomass is relatively stronger than the decrease in adult biomass, which results in a lower juvenile:adult biomass ratio in the population (Figure 6). This stems partly from faster maturation of the juveniles (results not shown) and partly from a lower production of juveniles by adults.

Based on the results of the consumer-resource model, a shift to severely $\mathrm{P}$ limited phytoplankton with a C:P ratio $>600$ is sufficient to reduce the abundance of daphnia and reduce the relative abundance of juvenile daphnia biomass. These model predictions may change with the use of different parameter values. In summary, our results indicate that the shift in $\mathrm{P}$ concentration in the surface water of lake 

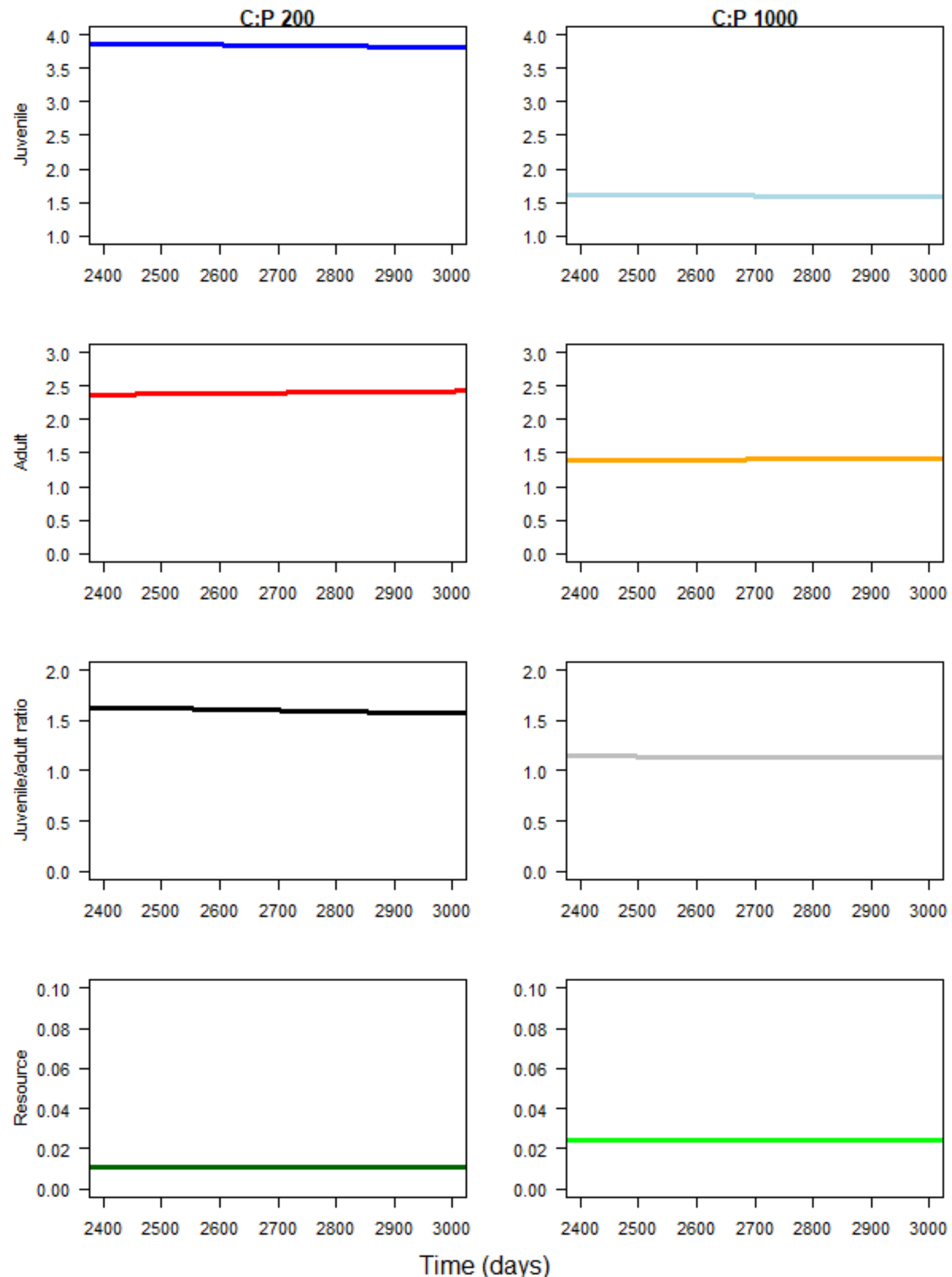

Figure 6 Juvenile and adult biomass ( $\mu \mathrm{mol} \mathrm{C}$ ), ratio between juvenile and adult biomass and (phytoplankton-) resource biomass ( $\mu \mathrm{mol} \mathrm{C}$ ) over time. The values are plotted for a C:P ratio of the food source $\phi_{F}$ equal to 200 (left) and 1000 (right) 


\section{$4 \quad$ Discussion and conclusions}

Changes in stoichiometry of nutrient availability and absolute availability may lead to a range of changes at higher trophic levels in freshwater ecosystems. Especially a reduction in relative phosphorus abundance may be influential, as many freshwater lakes are phosphor limited. Fish and zooplankton have species specific nutrient requirements that change over their ontogeny. Phosphorus is an essential nutrient for growth, and phosphorus deficiencies may lead to growth retardation. In addition to changes in nutrient content, fish and zooplankton may be confronted with changes in sizedistributions of their prey.

The nitrogen to phosphorus ratio in Lake IJssel has increased with a factor 10 over the last decades (Figure 1). This is due to a much more efficient reduction of phosphorus than nitrogen in wastewater effluents that flow to Lake IJssel. It is unclear to what extend the changes in stoichiometry of the nutrient availability are responsible for the changes at higher trophic levels in Lake IJssel. While for example the abundance of smelt has decreased quite dramatically (Figure 1), there are several factors that could be responsible for this change. Examples of such causes are the commercial exploitation of smelt, changes in hydrological regime and changes in the Lake IJssel food web (de Leeuw et al. 2019).

The analysis of a life history model of Daphnia, which includes carbon and phosphorus based energy budgets, shows that a shift in severity of P limitation such as observed in Lake IJssel (Figure $\mathbf{3}$ ) can strongly reduce zooplankton growth and reproduction (Figure 5). Such reduced energy availability for Daphnia may lead to a lower productivity and shift in the size distribution of the Daphnia population (Figure 6) and subsequently to a reduction of food for fish such as smelt.

Previous theoretical studies have shown complex dynamics with stoichiometry in food chain dynamics (Andersen et al. 2004, Kuijper et al. 2004). Our theoretical exploration does not show such complexity. When the nutrient ratio in the resource in the model changes, there simply occurs a shift from limitation by one nutrient to limitation by another nutrient. Different parameter values may lead to more complexity. In addition, the observed shift in the size distribution could be enhanced by the implementation of (more realistic) size-dependent parameters for food-ingestion and metabolic maintenance (de Roos 2018). Nonetheless, the results underline the potential for phosphorus limitation in food chains when the phosphorus loading in water bodies is reduced. A decrease in zooplankton quantity and quality due to lower phosphorus in their diet may lead to a reduced food availability for zooplanktivorous fish.

A potential way to detect a direct $P$ deficiency in smelt would be through an analysis of the growth patterns of smelt, but it is questionable whether the data available is of sufficient quality to do a thorough analysis. Observations of $P$ limitation in fish is rare in nature (Schindler and Eby 1997). Fish may adjust their behaviour to compensate for low $P$ intake. If the changes in nutrient availability have affected smelt, this has most likely come about through a change in the zooplankton species composition, abundance and/or size distribution. Daphnids as well as rotifers require a higher $\mathrm{P}$ content in their diet than for example copepods and the cladoceran Bosmina. Since there is no consistent sampling of the zooplankton community in Lake IJssel it is probably hard to detect whether a change in species composition has actually occurred. Yet, some data is available and it could be worthwhile to analyse them with this focus (Figure 2). Generally, the zooplankton composition is the key to finding out more about the effects of different nutrient ratios on the higher trophic levels. A consistent zooplankton sampling program of species composition, size distribution and stoichiometry is essential to increase understanding of the changes throughout the food chain of Lake IJssel.

Experimental work that assesses the effect of changes in stoichiometry in the phytoplankton on growth and food intake of zooplankton (Sarpe et al. 2014) and fish would be very valuable in showing the potential of changes in stoichiometry of surface waters on aquatic food chains. 
Eutrophication of Dutch lakes due to external inputs of $\mathrm{N}$ and $\mathrm{P}$ in the 1950 s led to poor water quality with high turbidity, cyanobacterial blooms and few littoral vegetation (Gulati and van Donk 2002). The recent reductions of $\mathrm{N}$ and $\mathrm{P}$ inputs to freshwater systems have improved water quality in many freshwater bodies in and around the Netherlands. Since phosphorus reductions are often more efficient than nitrogen reductions this improvement of water quality goes in many cases hand in hand with a change in stoichiometry. The effects of stoichiometry on ecological systems can be extensive (Sterner and Elser 2002). It is not straightforward to predict how changes in stoichiometry affect higher trophic levels in aquatic food chains. In addition to changes in the pelagic ecosystem, changes in stoichiometry may affect the benthic energy pathway, because many planktivores, such as smelt, include benthic animals in their diet (de Leeuw et al. 2006). Also, many fish eating birds depend on smelt to raise their chicks. Moreover, environmental factors, such as temperature, may affect stoichiometry. The consideration of stoichiometry is therefore also highly relevant in the perspective of climate change (Waal et al. 2010, Domis et al. 2014). Future developments of nutrient run-off measures are targeted at the limitation of $\mathrm{N}$ effluents. Yet, it is unclear what will happen in case there is a switch from $\mathrm{P}$ limited to $\mathrm{N}$ limited states in freshwater ecosystems. So far, it is even unclear how likely it is that such a switch may occur due to changes in nutrient run-off. 


\section{Quality Assurance}

Wageningen Marine Research utilises an ISO 9001:2015 certified quality management system. This certificate is valid until 15 December 2021. The organisation has been certified since 27 February 2001. The certification was issued by DNV GL.

Furthermore, the chemical laboratory at IJmuiden has EN-ISO/IEC 17025:2017 accreditation for test laboratories with number L097. This accreditation is valid until $1^{\text {th }}$ of April 2021 and was first issued on 27 March 1997. Accreditation was granted by the Council for Accreditation. The chemical laboratory at IJmuiden has thus demonstrated its ability to provide valid results according a technically competent manner and to work according to the ISO 17025 standard. The scope (L097) of de accredited analytical methods can be found at the website of the Council for Accreditation (www.rva.nl). 


\section{References}

Andersen, T., J. J. Elser, and D. O. Hessen. 2004. Stoichiometry and population dynamics: Stoichiometry and population dynamics. Ecology Letters 7:884-900.

Andersen, T., and D. O. Hessen. 1991. Carbon, nitrogen, and phosphorus content of freshwater zooplankton. Limnology and Oceanography 36:807-814.

Basińska, A. M., M. Antczak, K. Świdnicki, V. E. J. Jassey, and N. Kuczyńska-Kippen. 2014. Habitat type as strongest predictor of the body size distribution of Chydorus sphaericus (O. F. Müller) in small water bodies. International Review of Hydrobiology 99:382-392.

Benstead, J. P., J. M. Hood, N. V. Whelan, M. R. Kendrick, D. Nelson, A. F. Hanninen, and L. M. Demi. 2014. Coupling of dietary phosphorus and growth across diverse fish taxa: a meta-analysis of experimental aquaculture studies. Ecology 95:2768-2777.

Brooks, J. L. 1968. The Effects of Prey Size Selection By Lake Planktivores. Systematic Zoology $17: 273-291$.

Burson, A., M. Stomp, L. Akil, C. P. D. Brussaard, and J. Huisman. 2016. Unbalanced reduction of nutrient loads has created an offshore gradient from phosphorus to nitrogen limitation in the North Sea. Limnology and Oceanography 61:869-888.

Cumminns, K. W., and J. C. Wuycheck. 1971. Caloric Equivalents for Investigations in Ecological Energetics. SIL Communications, 1953-1996 18:1-158.

Diana, J. S., C. K. Lin, and P. J. Schneeberger. 1991. Relationships among nutrient inputs, water nutrient concentrations, primary production, and yield of Oreochromis niloticus in ponds. Aquaculture 92:323-341.

Dickman, E. M., M. J. Vanni, and M. J. Horgan. 2006. Interactive effects of light and nutrients on phytoplankton stoichiometry. Oecologia 149:676-689.

Domis, L. N. D. S., D. B. V. de Waal, N. R. Helmsing, E. V. Donk, and W. M. Mooij. 2014. Community stoichiometry in a changing world: combined effects of warming and eutrophication on phytoplankton dynamics. Ecology 95:1485-1495.

Downing, J. A., C. Plante, and S. Lalonde. 1990. Fish Production Correlated with Primary Productivity, not the Morphoedaphic Index. Canadian Journal of Fisheries and Aquatic Sciences 47:19291936.

Ebert, D. 2005. Introduction to Daphnia Biology. National Center for Biotechnology Information (US).

Eertwegh, G. A. P. H. van den. 2002. Water and nutrient budgets at field and regional scale : travel times of drainage water and nutrient loads to surface water. phd, S.n., S.I.

Elser, J. J., M. M. Elser, N. A. Mackay, and S. R. Carpentef. 1988. Zooplankton-mediated transitions between $\mathrm{N}$ - and P-limited algal growth.

van Gerven, L., and P. Groenendijk. 2020. Vrachten van nutriënten en koolstof vanuit oppervlaktewater naar het Nederlandse deel van de Noordzee:27.

Griffiths, D. 2006. The direct contribution of fish to lake phosphorus cycles. Ecology of Freshwater Fish 15:86-95.

Gulati, R. D., and E. van Donk. 2002. Lakes in the Netherlands, their origin, eutrophication and restoration: state-of-the-art review. Hydrobiologia 478:73-106.

Guo, X.-T., F. Liu, and F. Wang. 2018. Carbon, Nitrogen, And Phosphorus Stoichiometry of Three Freshwater Cultured Fishes in Growth Stage:7.

Hall, S. R., M. A. Leibold, D. A. Lytle, and V. H. Smith. 2004. Stoichiometry and Planktonic Grazer Composition Over Gradients of Light, Nutrients, and Predation Risk. Ecology 85:2291-2301.

Hecky, R. E., P. Campbell, and L. L. Hendzel. 1993. The stoichiometry of carbon, nitrogen, and phosphorus in particulate matter of lakes and oceans. Limnology and Oceanography 38:709724.

Hecky, R. E., and P. Kilham. 1988. Nutrient limitation of phytoplankton in freshwater and marine environments: A review of recent evidence on the effects of enrichment1. Limnology and Oceanography 33:796-822.

Hessen, D. O. 1992. Nutrient Element Limitation of Zooplankton Production. The American Naturalist 140:799-814.

Hochstädter, S. 2000. Seasonal changes of C:P ratios of seston, bacteria, phytoplankton and zooplankton in a deep, mesotrophic lake. Freshwater Biology 44:453-463.

Karlsson, J., P. Byström, J. Ask, P. Ask, L. Persson, and M. Jansson. 2009. Light limitation of nutrientpoor lake ecosystems. Nature 460:506-509.

Kuijper, L. D. J., B. W. Kooi, T. R. Anderson, and S. A. L. M. Kooijman. 2004. Stoichiometry and foodchain dynamics. Theoretical Population Biology 66:323-339. 
Laspoumaderes, C., B. Modenutti, M. S. Souza, M. Bastidas Navarro, F. Cuassolo, and E. Balseiro. 2013. Glacier melting and stoichiometric implications for lake community structure: zooplankton species distributions across a natural light gradient. Global Change Biology 19:316-326.

de Leeuw, J. J., C. Deerenberg, W. Dekker, R. van Hal, and H. Jansen. 2006. Veranderingen in de visstand van het IJsselmeer en Markermeer: trends en oorzaken. Page 33.

de Leeuw, J. J., T. van der Hammen, A. Schadeberg, and K. Kwakman-Schilder. 2019. Spieringvisserij IJsselmeer en Waddenzee: Voorstudie ecologische risicoanalyse ten behoeve van afwegingskader spieringvisseri. Wageningen Marine Research.

Maranger, R., S. E. Jones, and J. B. Cotner. 2018. Stoichiometry of carbon, nitrogen, and phosphorus through the freshwater pipe: Stoichiometry of carbon, nitrogen, and phosphorus. Limnology and Oceanography Letters 3:89-101.

Noordhuis, R. 2010. Ecosysteem IJsselmeergebied: nog altijd in ontwikkeling. Page 421.

Pilati, A., and M. J. Vanni. 2007. Ontogeny, Diet Shifts, and Nutrient Stoichiometry in Fish 116:16631674.

Prater, C., P. C. Frost, E. T. Howell, S. B. Watson, A. Zastepa, S. S. E. King, R. J. Vogt, and M. A. Xenopoulos. 2017. Variation in particulate C: N : P stoichiometry across the Lake Erie watershed from tributaries to its outflow: Lake Erie C: N : P stoichiometry. Limnology and Oceanography 62:S194-S206.

Prater, C., N. D. Wagner, and P. C. Frost. 2016. Effects of calcium and phosphorus limitation on the nutritional ecophysiology of Daphnia. Limnology and Oceanography 61:268-278.

Rhee, G.-Y., and I. J. Gotham. 1980. Optimum N:p Ratios and Coexistence of Planktonic Algae. Journal of Phycology 16:486-489.

Richard, R., and A. M. de Roos. 2018. The impact of development on patterns of nutrient limitation. Functional Ecology 32:1507-1519.

Riemann, B., P. Simonsen, and L. Stensgaard. 1989. The carbon and chlorophyll content of phytoplankton from various nutrient regimes. Journal of Plankton Research 11:1037-1045.

van Rijssel, J. C., O. A. van Keeken, and J. J. de Leeuw. 2019. Vismonitoring zoete Rijkswateren en overgangswateren t/m 2018: Deel I: toestand en trends. Page 353. Wageningen Marine Research.

de Roos, A. M. 2018. When individual life history matters: Conditions for juvenile-adult stage structure effects on population dynamics. Theoretical Ecology 11:397-416.

de Roos, A. M., and L. Persson. 2013. Population and community ecology of ontogenetic development. Page in S. A. Levin and H. S. Horn, editors. Monographs in Population Biology, Volume 51. Princeton University Press, Princeton and Oxford.

Sarpe, D., L. de Senerpont Domis, S. Declerck, E. van Donk, and B. Ibelings. 2014. Food quality dominates the impact of food quantity on Daphnia life history: possible implications for reoligotrophication. Inland Waters 4:363-368.

Schindler, D. E., and L. A. Eby. 1997. Stoichiometry of Fishes and Their Prey: Implications for Nutrient Recycling. Ecology 78:1816-1831.

Schulz, K. L., and R. W. Sterner. 1999. Phytoplankton phosphorus limitation and food quality for Bosmina. Limnology and Oceanography 44:1549-1556.

Silins, U., K. D. Bladon, E. N. Kelly, E. Esch, J. R. Spence, M. Stone, M. B. Emelko, S. Boon, M. J. Wagner, C. H. S. Williams, and I. Tichkowsky. 2014. Five-year legacy of wildfire and salvage logging impacts on nutrient runoff and aquatic plant, invertebrate, and fish productivity. Ecohydrology 7:1508-1523.

Soudijn, F. H., and A. M. de Roos. 2017. Predator Persistence through Variability of Resource Productivity in Tritrophic Systems. The American Naturalist 190:844-853.

Sterner, R. W., T. Andersen, J. J. Elser, D. O. Hessen, J. M. Hood, E. McCauley, and J. Urabe. 2008. Scale-dependent carbon:nitrogen:phosphorus seston stoichiometry in marine and freshwaters. Limnology and Oceanography 53:1169-1180.

Sterner, R. W., J. Clasen, W. Lampert, and T. Weisse. 1998. Carbon:phosphorus stoichiometry and food chain production. Ecology Letters 1:146-150.

Sterner, R. W., and J. J. Elser. 2002. Ecological Stoichiometry: The biology of elements from molecules to the biosphere. Princeton Univeristy Press, Princeton.

Stubbington, R., J.-P. Hogan, and P. J. Wood. 2017. Characterization of the density and body size of a Gammarus pulex (Crustacea: Amphipoda) population in subsurface sediments reflects the sampling technique used. Hydrobiologia 788:293-303.

Van Leeuwen, A., A. M. De Roos, and L. Persson. 2008. How cod shapes its world. Journal of Sea Research 60:89-104.

Van Zuilekom, W. 1991. Invloed van temperatuur en zooplanktonaanbod op de groei van spiering (Osmerus eperlanus) en juveniele baars (Perca fluviatilis) in het IJsselmeer. .. Landbouw Universiteit Wageningen. 
Vanni, M. J., A. S. Flecker, J. M. Hood, and J. L. Headworth. 2002. Stoichiometry of nutrient recycling by vertebrates in a tropical stream: linking species identity and ecosystem processes. Ecology Letters 5:285-293.

Ventura, M., and J. Catalan. 2005. Reproduction as one of the main causes of temporal variability in the elemental composition of zooplankton. Limnology and Oceanography 50:2043-2056.

Villar-Argaiz, M., J. M. M. Sánchez, L. Cruz-Pizarro, and P. Carrillo. 2000. Life history implications of calanoid Mixodiaptomus laciniatus in C:N:P stoichiometry. SIL Proceedings, 1922-2010 27:527-531.

Vonk, J. A., T. Rombouts, J. C. Schoorl, P. Serne, J. W. Westerveld, P. Cornelissen, and H. G. van der Geest. 2017. Impact of water drawdown and rewetting on sediment nutrient-dynamics in a constructed delta-lake system (Oostvaardersplassen, The Netherlands): A mesocosm study. Ecological Engineering 108:396-405.

Waal, D. B. van de, A. M. Verschoor, J. M. Verspagen, E. van Donk, and J. Huisman. 2010. Climatedriven changes in the ecological stoichiometry of aquatic ecosystems. Frontiers in Ecology and the Environment 8:145-152.

Wang, L., H. Zhuang, Y. Zhang, and W. Wei. 2019. Diversity of the Bosmina (Cladocera: Bosminidae) in China, revealed by analysis of two genetic markers (mtDNA $16 \mathrm{~S}$ and a nuclear ITS). BMC Evolutionary Biology 19:145.

Weigelhofer, G., J. P. Ramião, B. Pitzl, E. Bondar-Kunze, and J. O'Keeffe. 2018. Decoupled watersediment interactions restrict the phosphorus buffer mechanism in agricultural streams. Science of The Total Environment 628-629:44-52.

Yu, L., J. Rozemeijer, B. M. van Breukelen, M. Ouboter, C. van der Vlugt, and H. P. Broers. 2018. Groundwater impacts on surface water quality and nutrient loads in lowland polder catchments: monitoring the greater Amsterdam area. Hydrology and Earth System Sciences 22:487-508. 


\section{Justification}

Report C003/21

Project Number: 5200046219

The scientific quality of this report has been peer reviewed by a colleague scientist and a member of the Management Team of Wageningen Marine Research

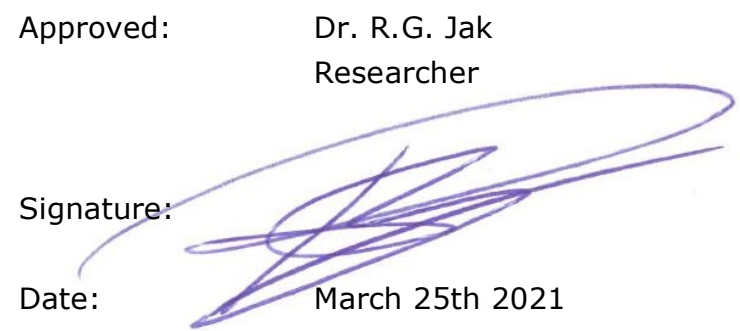

Approved: $\quad$ Drs. J. Asjes

Manager Integration

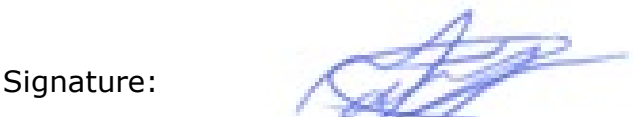

Date:

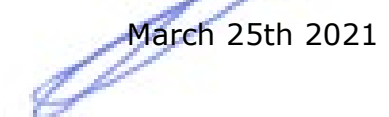


Wageningen Marine Research

$\mathrm{T}+31(0) 317480900$

E: marine-research@wur.nl

www.wur.eu/marine-research

Visitors' address

- Ankerpark 271781 AG Den Helder

- Korringaweg 7, 4401 NT Yerseke

- Haringkade 1, 1976 CP IJmuiden
With knowledge, independent scientific research and advice, Wageningen Marine Research substantially contributes to more sustainable and more careful management, use and protection of natural riches in marine, coastal and freshwater areas.
Wageningen Marine Research is part of Wageningen University \& Research. Wageningen University \& Research is the collaboration between Wageningen University and the Wageningen Research Foundation and its mission is: 'To explore the potential for improving the quality of life' 